\title{
High-resolution mapping of transcription factor binding sites on native chromatin
}

\author{
Sivakanthan Kasinathan ${ }^{1,2^{*}}$, Steven Henikoff ${ }^{1,3}$ \\ From Epigenetics \& Chromatin: Interactions and processes \\ Boston, MA, USA. 11-13 March 2013
}

Sequence-specific DNA-binding proteins including transcription factors (TFs) are key determinants of gene regulation and chromatin architecture. Formaldehyde cross-linking and sonication followed by chromatin immunoprecipitation and sequencing (X-ChIP-seq) is the most widely used technique for genome-wide profiling of protein binding sites. However, there are many issues associated with X-ChIP including low resolution and poor specificity and sensitivity. Here, we implement native (i.e., without cross-linking) ChIP of micrococcal nucleasedigested chromatin followed by paired-end sequencing (N-ChIP-seq) for mapping binding sites of the structurally distinct budding yeast TFs Abf1 and Reb1. N-ChIP-seq reproducibly recovers Abf1 and Reb1 binding sites with higher specificity and sensitivity than other profiling methods and identifies both previously characterized and novel sites. Altering N-ChIP-seq conditions allows flexibility in modulating specificity and sensitivity of binding site detection. Further, unlike X-ChIP methods, N-ChIP-seq is not biased toward identifying sites in accessible chromatin. Taken together, these results suggest that N-ChIP-seq outperforms current X-ChIP methodologies for genome-wide profiling of TF binding sites.

\section{Author details}

${ }^{1}$ Basic Sciences Division, Fred Hutchinson Cancer Research Center, Seattle, WA 98109, USA. ${ }^{2}$ Medical Scientist Training Program and Molecular and Cellular Biology Graduate Program, University of Washington, Seattle, WA 98195, USA. ${ }^{3}$ Howard Hughes Medical Institute, Seattle, WA 98109, USA.

Published: 8 April 2013

'Basic Sciences Division, Fred Hutchinson Cancer Research Center, Seattle, WA 98109, USA

Full list of author information is available at the end of the article
doi:10.1186/1756-8935-6-S1-P114

Cite this article as: Kasinathan and Henikoff: High-resolution mapping of transcription factor binding sites on native chromatin. Epigentics \& Chromatin 2013 6(Suppl 1):P114.
Submit your next manuscript to BioMed Central and take full advantage of:

- Convenient online submission

- Thorough peer review

- No space constraints or color figure charges

- Immediate publication on acceptance

- Inclusion in PubMed, CAS, Scopus and Google Scholar

- Research which is freely available for redistribution

\section{() Biomed Central}

C Biomed Central

(c) 2013 Kasinathan and Henikoff; licensee BioMed Central Ltd. This is an Open Access article distributed under the terms of the Creative Commons Attribution License (http://creativecommons.org/licenses/by/2.0), which permits unrestricted use, distribution, and reproduction in any medium, provided the original work is properly cited. 